\title{
A comparison of the environmental impact of Jersey compared with Holstein milk for cheese production ${ }^{1}$
}

\author{
J. L. Capper ${ }^{2}$ and R. A. Cady† \\ *Department of Animal Sciences, Washington State University, Pullman 99164 \\ †Elanco Animal Health, Greenfield, IN 46140
}

\section{ABSTRACT}

The objective of this study was to compare the environmental impact of Jersey or Holstein milk production sufficient to yield 500,000 t of cheese (equivalent cheese yield) both with and without recombinant bovine somatotropin use. The deterministic model used 2009 DairyMetrics (Dairy Records Management Systems, Raleigh, NC) population data for milk yield and composition (Jersey: $20.9 \mathrm{~kg} / \mathrm{d}, 4.8 \%$ fat, $3.7 \%$ protein; Holstein: $29.1 \mathrm{~kg} / \mathrm{d}, 3.8 \%$ fat, $3.1 \%$ protein), age at first calving, calving interval, and culling rate. Each population contained lactating and dry cows, bulls, and herd replacements for which rations were formulated according to DairyPro (Agricultural Modeling and Training Systems, Cornell, Ithaca, NY) at breedappropriate body weights (BW), with mature cows weighing $454 \mathrm{~kg}$ (Jersey) or $680 \mathrm{~kg}$ (Holstein). Resource inputs included feedstuffs, water, land, fertilizers, and fossil fuels. Waste outputs included manure and greenhouse gas emissions. Cheese yield $(\mathrm{kg})$ was calculated according to the Van Slyke equation. A yield of 500,000 $\mathrm{t}$ of cheese required 4.94 billion $\mathrm{kg}$ of Holstein milk compared with 3.99 billion $\mathrm{kg}$ of Jersey milk - a direct consequence of differences in milk nutrient density (fat and protein contents) between the 2 populations. The reduced daily milk yield of Jersey cows increased the population size required to supply sufficient milk for the required cheese yield, but the differential in BW between the Jersey and Holstein breeds reduced the body mass of the Jersey population by $125 \times 10^{3} \mathrm{t}$. Consequently, the population energy requirement was reduced by $7,177 \times 10^{6} \mathrm{MJ}$, water use by $252 \times 10^{9}$ $\mathrm{L}$, and cropland use by $97.5 \times 10^{3}$ ha per $500,000 \mathrm{t}$ of cheese yield. Nitrogen and phosphorus excretion were reduced by 17,234 and 1,492 $\mathrm{t}$, respectively, through the use of Jersey milk to yield 500,000 t of Cheddar cheese.

Received March 14, 2011.

Accepted September 20, 2011.

${ }^{1}$ Major funding for this work was supplied by National All-Jersey Inc., Reynoldsburg, $\mathrm{OH}$.

${ }^{2}$ Corresponding author: capper@wsu.edu
The carbon footprint was reduced by $1,662 \times 10^{3} \mathrm{t}$ of $\mathrm{CO}_{2}$-equivalents per 500,000 $\mathrm{t}$ of cheese in Jersey cows compared with Holsteins. Use of recombinant bovine somatotropin reduced resource use and waste output in supplemented populations, with decreases in carbon footprint equivalent to $10.0 \%$ (Jersey) and $7.5 \%$ (Holstein) compared with nonsupplemented populations. The interaction between milk nutrient density and BW demonstrated by the Jersey population overcame the reduced daily milk yield, thus reducing resource use and environmental impact. This reduction was achieved through 2 mechanisms: diluting population maintenance overhead through improved milk nutrient density and reducing maintenance overhead through a reduction in productive and nonproductive body mass within the population.

Key words: Jersey, Holstein, environmental impact, dilution of maintenance

\section{INTRODUCTION}

The environmental sustainability of animal agriculture has recently undergone considerable scrutiny as this issue comes to the fore of political, social, and economic agendas (Food and Agriculture Organization, 2006, 2010). Improving productivity demonstrably reduces the environmental impact of dairy production (Capper et al., 2008, 2009). This is achieved through the "dilution of maintenance" (DOM) concept, whereby the maintenance nutrient requirement is spread over increased units of production, reducing natural resource use and greenhouse gas (GHG) emissions per unit of milk.

Previous research on the interaction between productivity and environmental impact has focused on the effect of changing milk production per cow, with DOM having an effect at both the individual animal and the supporting herd or population level. However, the roles of other animal performance characteristics that affect population maintenance overhead warrant further investigation. As maintenance nutrient requirements are directly affected by BW and activity level, an opportunity to reduce total maintenance overhead through 
changes in BW while maintaining dairy production would be predicted to reduce the environmental impact of milk production. Similarly, the potential environmental effect of changes in performance characteristics such as age at first calving (AFC), herd life, and calving interval $(\mathbf{C I})$ that affect the dynamics and size of the supporting population have not yet been quantified.

Over the past $65 \mathrm{yr}$, per capita consumption of fluid milk has declined and cheese consumption has increased (National Milk Producers Federation, 2009). Given that over $40 \%$ of milk produced in the United States is currently used for cheese production, it is appropriate to assess the environmental effects of improved productivity not simply as a function of milk yield, but as the interaction between milk yield and milk nutrient density (fat and protein content), which is the major determinant of cheese yield. Increasing milk nutrient density would be predicted to reduce the quantity of milk required for cheese production and thus to have a positive effect upon environmental impact, although this effect is yet to be quantified.

The US dairy herd comprises $90.1 \%$ Holstein and $5.3 \%$ Jersey cattle (USDA, 2007a), 2 breeds that display very different performance characteristics, notably a higher milk yield in the Holstein breed compared with a higher milk nutrient density and a lesser BW in the Jersey breed. The environmental impact of recombinant bovine somatotropin ( $\mathbf{r b S T}$ ) has been evaluated in Holstein populations (Johnson et al., 1992; Dunlap et al., 2000; Capper et al., 2008) but the effect in smallframed dairy breeds with a generally lower daily milk yield has not yet been defined. In this study, we used a deterministic model to assess the environmental impact of producing sufficient milk to yield 500,000 t of Cheddar cheese from either the Jersey or Holstein populations using national data for production year 2009, with and without rbST supplementation.

\section{MATERIALS AND METHODS}

This study used data from existing reports and databases and required no approval from an animal care and use committee. Environmental impact was assessed using a deterministic model based on animal nutrition and metabolism and founded on life cycle assessment (LCA) principles. The model was designed to compare the environmental impact of milk production from 4 populations, each containing either Holstein or Jersey cows, with and without rbST supplementation.

The system boundaries extended from the production of feed and forage crops (including crop input manufacture) through and including milk harvest. It did not include milk transportation, off-farm processing, packaging, or consumption. The functional unit by which environmental impact was assessed was the amount of milk required to manufacture 500,000 t of Cheddar cheese yielded over a 365 -d period. The amount of milk required for Cheddar cheese production from each population was calculated from the Van Slyke equation for Cheddar cheese yield (Coggins, 1991): $\mathrm{CY}=(0.93 \mathrm{MF}$ $+0.80 \mathrm{P}-0.1) \times 1.09 /(1$ - desired $\mathrm{M} / 100)$, where $\mathrm{CY}$ is Cheddar cheese yield, MF is milkfat, $\mathrm{P}$ is milk protein, and $\mathrm{M}$ is the desired cheese moisture content. Cheddar cheese yield was set at 500,000 t and cheese moisture at a standard of $37 \%$ for Cheddar (Coggins, 1991). The milk required for Cheddar cheese production was calculated according to breed-specific milkfat and protein concentrations at $0.101 \mathrm{~kg}$ of cheese $/ \mathrm{kg}$ of milk (Holstein) and $0.125 \mathrm{~kg}$ of cheese $/ \mathrm{kg}$ of milk (Jersey; Table 1).

Breed-specific performance data were obtained from the DairyMetrics database (Dairy Records Management Systems, DRMS, Raleigh, NC; accessed November 13, 2009) and are summarized in Table 1. Performance data were based on breed averages from 1.88 million Holstein cows located in 12,374 herds, and 68,916 Jersey cows from 634 herds located throughout the United States. The Holstein population averaged $29.1 \mathrm{~kg}$ of milk daily $(9,554 \mathrm{~kg}$ rolling herd average, RHA) with milk components for milkfat and protein averaging 3.8 and $3.1 \%$, respectively. Jersey cows averaged $20.9 \mathrm{~kg}$ of milk daily (6,467 $\mathrm{kg}$ RHA) with a milkfat concentration of $4.8 \%$ and protein content of $3.7 \%$. Holsteins had a longer average CI (14.1 mo) than Jerseys (13.7 mo) and a later AFC at 26.1 mo compared with 25.3 mo. The culling rate was converted from a removal rate (includes culls and deaths) to an estimated herd life. The annual Holstein removal rate was $34.5 \%$, which was equivalent to an expected herd life of 2.54 lactations, whereas Jersey cows had a removal rate of $30.0 \%$, corresponding to an expected herd life of 3.0 completed lactations. The average number of days dry was not directly available from the DRMS DairyMetric system, but available information indicated that it did not differ significantly between the 2 breeds. Thus, average days dry for both breeds was set to a typical US goal of 60 d (USDA, 2007a). Average SCC did not differ significantly between the 2 populations and was set at 250,000, the DRMS DairyMetric system-wide average. Somatic cell count was used within the model as a proxy to calculate milk loss resulting from mastitis (Raubertas and Shook, 1982).

Supplementation with rbST was modeled according to FDA-approved guidelines (Posilac, Elanco Animal Health, Greenfield, IN) that indicates supplementation may commence any day between 57 and 70 DIM and continuing every $14 \mathrm{~d}$ until the end of lactation. Supplementation within the current model was set to com- 
Table 1. Breed-specific performance data inputs to the model

\begin{tabular}{|c|c|c|}
\hline $\begin{array}{l}\text { Performance } \\
\text { characteristic }\end{array}$ & Holstein & Jersey \\
\hline 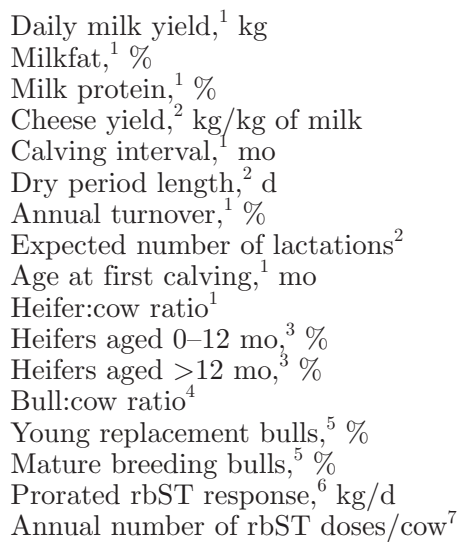 & $\begin{array}{l}29.1 \\
3.8 \\
3.1 \\
0.101 \\
14.1 \\
60 \\
34.5 \\
2.54 \\
26.1 \\
0.86 \\
46.2 \\
53.8 \\
0.023 \\
46.2 \\
53.8 \\
3.4 \\
16.4\end{array}$ & $\begin{array}{l}20.9 \\
4.8 \\
3.7 \\
0.125 \\
13.7 \\
60 \\
30.0 \\
3.00 \\
25.3 \\
0.83 \\
48.0 \\
52.0 \\
0.027 \\
45.4 \\
54.6 \\
3.4 \\
18.0\end{array}$ \\
\hline \multicolumn{3}{|c|}{${ }^{1}$ Data from DairyMetrics database (Dairy Records Management Systems, Raleigh, NC); accessed November } \\
\hline \multicolumn{3}{|c|}{$\begin{array}{l}{ }^{2} \text { Calculated as a function of data from DairyMetrics database (Dairy Records Management Systems); accessed } \\
\text { November } 13,2009 \text {. }\end{array}$} \\
\hline \multicolumn{3}{|c|}{${ }^{3}$ Calculated as a function of the heifer:cow ratio and age at first calving. } \\
\hline \multicolumn{3}{|c|}{$\begin{array}{l}{ }^{4} \text { Calculated as a function of postpubescent female cattle within the herd, calving interval, AI adoption (de } \\
\text { Vries et al., 2008), and the recommended number of bulls per cow (Overton, 2005). }\end{array}$} \\
\hline \multirow{2}{*}{\multicolumn{3}{|c|}{$\begin{array}{l}(36 \mathrm{mo}) \text {. } \\
\text { (3alculed as a function of the bull:cow ratio and assumed age at adolescent stage ( } 25 \mathrm{mo} \text { ) versus maturity } \\
\text { Pell et al., 1992; Ruegg et al., 1998; Bauman et al., 1999; Collier et al., 2001), prorated according to the propor- } \\
\text { tion of noneligible cows within the milking cow population. }\end{array}$}} \\
\hline & & \\
\hline \multicolumn{3}{|c|}{$\begin{array}{l}{ }^{7} \text { Calculated from the state date of recombinant bST (rBST) supplementation (63 DIM), calving interval, and } \\
\text { number of lactations in the herd for each breed. }\end{array}$} \\
\hline
\end{tabular}

mence at 63 DIM. Under these guidelines, and with the reproductive parameters used in this model, each cow was eligible for 16.4 (Holstein) or 18.0 (Jersey) doses of rbST on an annual pro-rated basis. This difference exists due to variation in CI between the 2 populations because cows with longer CI have a greater proportion of days eligible for rbST supplementation. However, in this comparison, Jersey cows spent an extra 0.46 lactations in the milk herd, which gave them more opportunity for rbST supplementation eligibility. Milk yield response to $\mathrm{rbST}$ was based on data that demonstrate a central tendency toward $4.5 \mathrm{~kg} / \mathrm{d}$ (Hartnell et al., 1991; Pell et al., 1992; Ruegg et al., 1998; Bauman et al., 1999; Collier et al., 2001). Previous data indicate that rbST use has no significant effect on culling (Ruegg et al., 1998; Bauman et al., 1999); therefore, no adjustment in replacement rate was required for rbST use. Mastitis incidence has been associated with an increase in milk yield; however, studies have shown no significant changes in the severity or duration of mastitis in rbSTsupplemented animals in commercial use (McClary et al., 1994; White et al., 1994; Judge et al., 1997; Tauer and Knoblauch, 1997; Ruegg et al., 1998; Bauman et al., 1999; Collier et al., 2001).
Each dairy population contained both productive animals (lactating cows) and supporting nonproductive animals (dry cows, replacement heifers, and mature and adolescent bulls). Calves not destined as replacement animals (e.g., bull calves and freemartins) were assumed to leave the population immediately after birth.

Population sizes and structures were determined by a lactation model according to the annual production requirement for 500,000 t of cheese yielded given the reported performance factors. Previous studies (Keown et al., 1984; Knight et al., 1998) indicated that increases in US milk production have been due to an increase in the height of the lactation curve rather than a change in the shape of the curve (i.e., no change in persistency). Furthermore, no evidence exists to suggest that the shape of lactation production curves differs according to breed, thus, 2 standard-shaped lactation curves were used, one for primiparous cows and one for multiparous cows. The multiparous lactation curve was used for lactations 2 through 5 and accounted for differences in maturity (Keown et al., 1984). Once lactation curves were established, performance factors (AFC, days dry, CI, SCC, and expected herd life) were fitted simultaneously by lengthening and shortening production cycles 
Table 2. Body weight and performance data for each feeding group within the model for the Holstein versus Jersey comparison

\begin{tabular}{|c|c|c|c|c|c|c|}
\hline \multirow[b]{2}{*}{ Dietary group } & \multicolumn{3}{|c|}{ Holstein } & \multicolumn{3}{|c|}{ Jersey } \\
\hline & $\begin{array}{c}\text { BW, } \\
\mathrm{kg}\end{array}$ & $\begin{array}{c}\text { Milk } \\
\text { yield, }{ }^{1} \mathrm{~kg} / \mathrm{d}\end{array}$ & $\begin{array}{l}\text { Growth } \\
\text { rate, }{ }^{2} \mathrm{~kg} / \mathrm{d}\end{array}$ & $\begin{array}{c}\text { BW, } \\
\mathrm{kg}\end{array}$ & $\begin{array}{c}\text { Milk } \\
\text { yield, } \mathrm{kg} / \mathrm{d}\end{array}$ & $\begin{array}{l}\text { Growth } \\
\text { rate, } \mathrm{kg} / \mathrm{d}\end{array}$ \\
\hline \multicolumn{7}{|l|}{ Primiparous lactating cows ${ }^{3}$} \\
\hline 4.5 to $13.5 \mathrm{~kg} / \mathrm{d}$ & 590 & - & 0.246 & 408 & 13.0 & 0.125 \\
\hline 13.6 to $27.1 \mathrm{~kg} / \mathrm{d}$ & 590 & 23.0 & 0.246 & 408 & 20.4 & 0.125 \\
\hline 27.2 to $40.7 \mathrm{~kg} / \mathrm{d}$ & 590 & 30.6 & 0.246 & 408 & - & 0.125 \\
\hline 40.8 to $54.3 \mathrm{~kg} / \mathrm{d}$ & 590 & - & 0.246 & 408 & - & 0.125 \\
\hline 54.4 to $68.0 \mathrm{~kg} / \mathrm{d}$ & 590 & - & 0.246 & 408 & - & 0.125 \\
\hline \multicolumn{7}{|l|}{ Multiparous lactating cows ${ }^{3}$} \\
\hline 4.5 to $13.5 \mathrm{~kg} / \mathrm{d}$ & 680 & 13.5 & - & 454 & 10.0 & - \\
\hline 13.6 to $27.1 \mathrm{~kg} / \mathrm{d}$ & 680 & 20.0 & - & 454 & 20.7 & - \\
\hline 27.2 to $40.7 \mathrm{~kg} / \mathrm{d}$ & 680 & 35.0 & - & 454 & 31.7 & - \\
\hline 40.8 to $54.3 \mathrm{~kg} / \mathrm{d}$ & 680 & 42.4 & - & 454 & - & - \\
\hline 54.4 to $68.0 \mathrm{~kg} / \mathrm{d}$ & 680 & - & - & 454 & - & - \\
\hline Far-off dry cows & 680 & - & - & 454 & - & - \\
\hline Close-up dry cows & 680 & - & - & 454 & - & - \\
\hline Replacement heifers $0-12 \mathrm{mo}$ & 165 & - & 0.668 & 113 & - & 0.461 \\
\hline Replacement heifers $>12 \mathrm{mo}$ & 415 & - & 0.607 & 280 & - & 0.420 \\
\hline Adolescent bulls & 385 & - & 0.898 & 265 & - & 0.621 \\
\hline Mature bulls & 1,089 & - & - & 726 & - & - \\
\hline
\end{tabular}

${ }^{1}$ Values derived from the dynamics of the dairy population producing required an average milk yield of $29.1 \mathrm{~kg} / \mathrm{d}$ (Holstein) or $20.9 \mathrm{~kg} / \mathrm{d}(\mathrm{Jersey})$ across all lactating cows as described in the Materials and Methods section. Average milk yield values shown for non-recombinant bST (rbST) population; add $3.4 \mathrm{~kg} / \mathrm{d}$ for the rbST-supplemented population.

${ }^{2}$ Predicted by the breed-specific weights at birth (43 kg for Holstein calves, $28 \mathrm{~kg}$ for Jersey calves) and first calving (545 kg for Holstein calves, $363 \mathrm{~kg}$ for Jersey calves) and ages at first calving (26.1 mo for Holstein, 25.3 mo for Jersey).

${ }^{3}$ Groups with a "—." value for milk yield or growth rate did not contain any animals in this comparison.

and adjusting the curves up or down until the stated average daily milk performance was generated from the modeled curves. As a check, the resulting RHA was computed and the final model adjusted in an iterative manner until the computed RHA was within $1 \%$ of the reported RHA, and average daily milk was equal to the reported performance. Because lactation curves 1 through 5 were fixed in shape, adjustments to average production were made simply by adjusting the curves up or down with a constant in 0.05-kg increments added to the daily milk weights until the average milk weight across all milk weights was equal to the average daily production in DRMS. The required number of milking cows was derived from the average daily milk production, and that of dry cows from expected herd life and days dry. The number of replacement heifers within the population was determined based on sex ratio at birth, twinning rate (including estimated incidence of freemartinism), mortality rates at various ages, reproductive losses (USDA, 2007b), and using the reported AFC from the DRMS DairyMetrics system. Artificial insemination accounts for $70 \%$ of successful conceptions (de Vries et al., 2008); therefore, sufficient bulls were included in the population to represent $30 \%$ of conceptions at a bull:cow ratio of 1:25 (Overton, 2005), plus AI bulls (including the young sire programs).

Lactating cows were assigned to up to 5 feeding groups according to milk production, with separate groups for primiparous and multiparous cows. Thus, depending on average level of production, up to 10 different lactating cow feeding groups were possible (Table 2). Dry cows were divided into a far-off and close-up group, heifers into 2 age groups, and bulls into adolescent and mature feeding groups.

To investigate rbST supplementation, lactation curves were modified to reflect the effect of an average $4.5-\mathrm{kg}$ increase in milk production, starting at 63 DIM through the last day of lactation. The 14-d cyclical nature of the rbST-induced production increase was accounted for, but no other performance characteristics were modified. The environmental impact of Posilac manufacture, use, and disposal were accounted for in the model according to the full LCA published by Hogan (2009). Supplementation with rbST slightly increases the labor requirement for cow management; however, quantification of labor use associated with different breeds or management practices was outside the scope of this manuscript.

Rations were formulated to meet the nutrient requirements of each group of animals within each dairy population according to BW, milk yield (lactating cows only), and growth rate (where appropriate; Table 2 ). Considerable differences in heat-stress tolerance would exist between the 2 breeds in specific regions of the United States; however, the main purpose of this study was to identify the effects of BW, milk yield, and milk nutrient composition, thus it was assumed that all animals were at thermoneutrality. All rations 
were formulated using DairyPro (Agricultural Modeling and Training Systems, Cornell, Ithaca, NY; AMTS, 2010) using the most commonly used feed ingredients (corn silage, alfalfa hay, dry ground corn grain, soybean meal) as defined by Mowrey and Spain (1999), with the addition of wheat straw and grass hay to balance rations when required. Manure output was based on an average diet digestibility factor across all diets of 0.65 (Capper et al., 2009). Daily nitrogen and phosphorus excretion for each animal group were calculated using DairyPro (AMTS, 2010).

As per common practice within the US dairy industry, Holstein bull and freemartin calves were assumed to leave the dairy system at $3 \mathrm{~d}$ of age to be reared as beef animals. The resource use and waste output from the rearing of these animals is therefore allocated to beef production and is not included within this analysis. In contrast, Jersey calves are seldom reared for beef due to their small mature size, thus Jersey bull and freemartin calves were assumed to be killed and composted just after birth. Carbon emissions from composting were calculated according to Payne and Pugh (2011) from the carbon content (14.5\% of liveweight) of a $28-\mathrm{kg}$ calf, assuming that all carcass carbon would be converted to atmospheric methane with $100 \%$ efficiency. An efficiency of this magnitude is unlikely to occur; however, in the absence of more precise data, it acts as to reinforce the conservative nature of the comparison between Jersey and Holstein. It is acknowledged that the practice of killing and composting calves is unlikely to be acceptable to the consumer and thus could threaten the social sustainability of dairy production from Jersey calves. The use of this practice within this model does not imply that the practice is condoned by the authors: adoption of sexed semen or improved management of Jersey calves raised for beef would reduce this loss within the system.

Dietary soluble residue, hemicellulose, and cellulose intakes were used to calculate enteric methane production from all animals within each population (Moe and Tyrrell, 1979). The fraction of nitrogen emitted as enteric nitrous oxide was calculated from data reported by Kaspar and Tiedje (1981) and Kirchgessner et al. (1991). Methane emissions from stored manure were estimated using methodology prescribed by the US Environmental Protection Agency (US EPA, 2010) based on the quantity of volatile solids (i.e., the volatile components of feces) excreted, maximum methaneproducing potential $\left(0.24 \mathrm{~m}^{3} / \mathrm{kg}\right.$ of volatile solids $)$, and a conversion factor (21.7) for liquid storage systems. Intergovernmental Panel on Climate Change (IPCC, 2006) emission factors were used to calculate nitrous oxide emissions from manure. Biogenic carbon, which rotates continuously through the relatively short-term cycle from the atmosphere into crops and animals and back to the atmosphere through animal respiration, was considered neutral with respect to GHG emissions. Carbon sequestration into plant tissue and $\mathrm{CO}_{2}$ produced through animal respiration were considered to balance and were not specifically accounted for.

The breed-specific performance data gathered from DairyMetrics were based on a 12-mo RHA for each breed, extending from November 2008 to November 2009. The majority of the feed supplied to animals within this database would have been harvested in 2008; therefore, total land use was derived from a function of the annual whole population feed requirement and published crop yields for 2008 according to USDA-NASS (2010). Fertilizer application rates for crop production were according to the most recently published US data for corn (USDA-NASS, 2006) and soybeans (USDA-NASS, 2007); data for alfalfa from Pimentel and Pimentel (2007); and data from Barnhart et al. (2008) for grass hay. Wheat straw was considered a by-product of wheat production, thus straw harvesting inputs were included according to Pimentel and Pimentel (2007), but all fertilizer inputs were allocated to the grain portion of the wheat crop. Nitrous oxide emissions from fertilizer application were estimated from the factors published by the IPCC (2006). Carbon dioxide emissions from fertilizer and pesticide manufacture were derived from West and Marland (2002), and similar emissions from fossil fuel combustion for crop production were calculated from US EPA (2010). Due to a lack of reliable data and the number of assumptions involved in applying a land use factor to cropland, carbon sequestered into soil was not included in the model calculations.

Voluntary water intake for each class of animal was calculated according to Holter (1992), with daily sanitation water (used for cleaning and disinfection of milking equipment) added at a rate of $28.4 \mathrm{~L}$ per lactating cow. Annual electricity use for cattle housing (e.g., lighting and ventilation) was $326 \mathrm{~kW}$ per animal, with an additional $247 \mathrm{~kW}$ per lactating cow for milk cooling and storage (Ludington and Peterson, 2005). The Energy Information Administration (2001) provided the data from which to calculate a nationwide factor for carbon dioxide emissions from electricity generation, which was applied to electricity use within the model. Total carbon footprint was calculated by applying carbon dioxide-equivalent factors from IPCC to methane (25) and nitrous oxide (298) to calculate the total carbon footprint as the sum of all methane, nitrous oxide and carbon dioxide emissions expressed in $\mathrm{CO}_{2}$-equivalents.

The environmental model was also used to investigate the contribution of individual breed-specific performance differences to the environmental impact 
of milk production for Cheddar cheese manufacture. From the original breed-specific data source, 6 specific performance characteristics differed between Jersey and Holstein populations with sufficient specificity that could be accounted for in the model. The 6 performance characteristics were BW, milk yield, milk nutrient density, herd life, AFC, and CI. A switch-over comparison changed a single characteristic (and all associated population inputs and outputs) while holding the other 5 characteristics constant, essentially providing for a Holstein population to receive a single Jersey characteristic (and vice versa), thus identifying the major factors influencing total environmental impact.

\section{RESULTS AND DISCUSSION}

The US dairy industry has made considerable progress in reducing the environmental impact of milk production, with a $63 \%$ decrease in the carbon footprint per unit of milk conferred by improved productivity between 1944 and 2007 (Capper et al., 2009). Implementing management practices and technologies that reduce natural resource use and environmental impact per unit of dairy production will become increasingly important as the global population and demand for milk increase. Productivity plays a major role in the total environmental impact of any food product. A recent report from the Food and Agriculture Organization (2010) concluded that industrialized nations produced milk with a smaller carbon footprint than developing nations. Examining the regional data shows that a negative relationship generally exists between annual milk production per cow and carbon footprint: as milk production increases, the carbon footprint decreases. On a national level, improving milk yield per cow has also been shown to reduce natural resource use and waste emissions per unit of milk (Capper et al., 2008).

As shown in Table 1, average Holstein milk yield was $8.2 \mathrm{~kg}$ greater than that of the Jersey cow. In a simple analysis that considers milk to be a generic product, regardless of nutrient density, it could be expected that the improved productivity from the Holstein would result in a lower environmental impact compared with the Jersey cow. However, as shown in Table 3, an extra $957 \times 10^{3}$ t of Holstein milk is required to yield 500,000 $\mathrm{t}$ of Cheddar cheese compared with the equivalent cheese production from Jersey cows. This is a direct consequence of the increased nutrient density of milk produced from Jersey cows which, according to the Van Slyke equation (Coggins, 1991), would result in a Cheddar cheese yield of $0.125 \mathrm{~kg}$ of cheese $/ \mathrm{kg}$ of milk compared with $0.101 \mathrm{~kg}$ of cheese $/ \mathrm{kg}$ of milk for the Holstein (Table 1). A considerable body of popular and scientific literature is currently devoted to comparing the environmental impact of food products (de Vries and de Boer, 2010; National Geographic, 2010; Peters et al., 2010), with the emphasis placed on consumers having the ability to make dietary choices that reduce resource use or GHG emissions. Labeling campaigns that show the carbon emissions of dairy products have also been undertaken by major grocery chains. Promoting consumer education concerning the effects of dietary choice upon environmental issues is a laudable endeavor; however, it is vital that the nutrient density of the foodstuffs is taken into account. Approximately $10 \mathrm{~kg}$ of milk is required to yield $1 \mathrm{~kg}$ of cheese, with a corresponding increase in environmental impact per kilogram. Consumers might therefore believe that fluid milk is a more suitable dietary choice than cheese, regardless of the increased nutrient density of cheese. All food has an environmental impact; it is essential therefore to compare not only per functional unit (kilogram or liter) but also on a standardized nutrient basis, which demonstrates the environmental advantage of improving milk nutrient density.

Productivity is conventionally assumed to refer to milk yield per cow, but within the current study, may also be defined as cheese yield per cow. As shown in Figure 1, the average Jersey cow yields $2.6 \mathrm{~kg}$ of Cheddar cheese/d, compared with $2.9 \mathrm{~kg}$ of Cheddar cheese/d from an average Holstein. Previous work demonstrated that improving productivity reduces the total number of animal required to produce a set amount of milk and, in consequence, environmental impact is reduced (Capper et al., 2008, 2009). As expected, therefore, the slight reduction in daily Cheddar cheese yield means that the Jersey population requires more lactating cows and a greater supporting population (dry cows, replacement heifers, mature and adolescent bulls; Table 3). The magnitude of the potential difference in supporting population size is somewhat mitigated by the lower heifer:cow ratio in the Jersey population resulting from the 0.8-mo difference in AFC.

One of the most notable features of the current analysis is the effect of animal BW upon natural resource use and environmental impact, an effect that has not been previously quantified. The DOM concept, whereby the proportion of total daily energy attributed to the maintenance requirement is reduced as milk yield increases, is the mechanism behind reductions in environmental impact at the individual animal and the supporting population level as a consequence of improved productivity (Capper et al., 2009). However, when comparing 2 populations kept within their thermoneutral zone and with similar activity levels, BW is the primary determinant of the underlying daily maintenance requirement upon which the DOM concept is founded. Reducing the daily maintenance requirement without adversely 


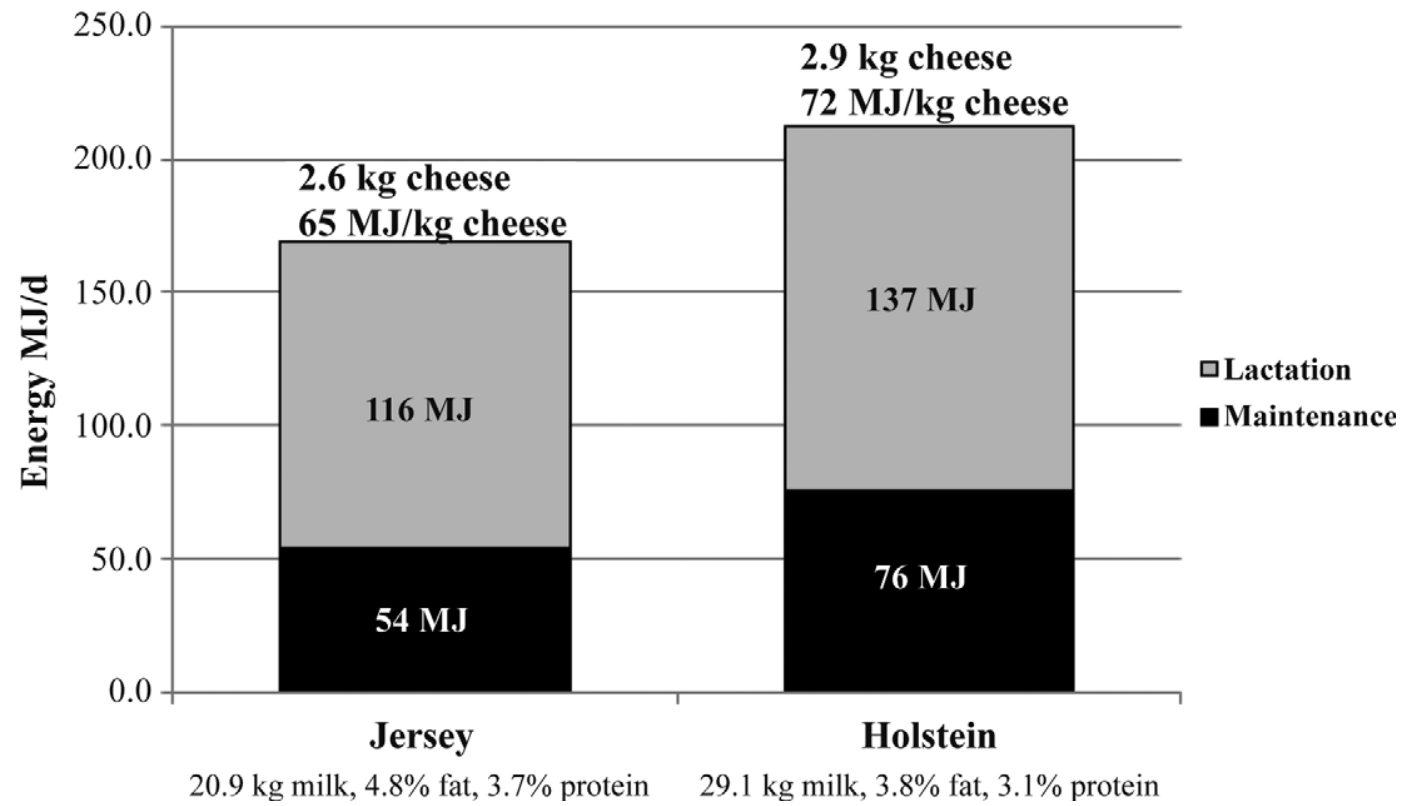

Figure 1. The effect of breed type, milk yield, milk composition, and relative proportion of daily energy used for maintenance versus lactation on energy use (and thus natural resource use) per kilogram of cheese.

affecting cheese yield would thus further affect the environmental impact of cheese production. The average Jersey cow, with a mature weight of $454 \mathrm{~kg}$, has a maintenance energy requirement of $54 \mathrm{MJ} / \mathrm{d}$ compared with $76 \mathrm{MJ} / \mathrm{d}$ for the Holstein, which, in combination with the increased Cheddar cheese yield per kilogram of milk, reduces the nutritional energy requirement per kilogram of cheese from $72 \mathrm{MJ}$ (Holstein) to $65 \mathrm{MJ}$ (Jersey). One of the underlying principles of LCA is to include all system inputs and outputs within the defined boundaries, which, in this case, extend from the cropping system (including crop input manufacture) to the farm gate. In consequence, the maintenance energy requirement of the supporting population must also be

Table 3. Annual natural resource use and environmental impact of producing 500,000 t of Cheddar cheese from Holstein or Jersey cows, with or without recombinant bST (rbST)

\begin{tabular}{|c|c|c|c|c|}
\hline \multirow[b]{2}{*}{ Item } & \multicolumn{2}{|c|}{ Holstein } & \multicolumn{2}{|c|}{ Jersey } \\
\hline & No rbST & $\operatorname{rbST}^{1}$ & No rbST & $\operatorname{rbST}^{1}$ \\
\hline Milk required, $\times 10^{3} \mathrm{t}$ & 4,944 & 4,944 & 3,987 & 3,987 \\
\hline Number of lactating cows $\times 10^{3}$ & 465.0 & 417.4 & 523.9 & 449.7 \\
\hline Total animals in the population $\times 10^{3}$ & 987.5 & 886.3 & 1,079 & 926.2 \\
\hline Population body mass, $\times 10^{3} \mathrm{t}$ & 484.6 & 435.0 & 359.6 & 308.6 \\
\hline Population maintenance energy requirement ${ }^{2}, \times 10^{6} \mathrm{MJ}$ & 26,545 & 23,750 & 20,624 & 17,639 \\
\hline Population total energy requirement ${ }^{2}, \times 10^{6} \mathrm{MJ}$ & 50,211 & 47,390 & 43,034 & 40,003 \\
\hline Feedstuffs, ${ }^{3} \times 10^{3} \mathrm{t}$ & 8,062 & 7,467 & 6,470 & 5,728 \\
\hline Land, ha $\times 10^{3}$ & 847.8 & 792.7 & 750.3 & 687.4 \\
\hline Water, $^{4} \times 10^{9} \mathrm{~L}$ & 796.8 & 720.5 & 544.8 & 479.3 \\
\hline Nitrogen excretion, $\mathrm{t}$ & 94,894 & 88,017 & 77,660 & 69,626 \\
\hline Phosphorus excretion, $\mathrm{t}$ & 10,550 & 9,701 & 9,058 & 8,077 \\
\hline Manure, $\times 10^{3} \mathrm{t}$ & 11,945 & 11,074 & 9,686 & 8,765 \\
\hline Methane, $\times 10^{3} \mathrm{t}$ & 269.2 & 247.6 & 210.7 & 188.2 \\
\hline Nitrous oxide, $\times 10^{3} \mathrm{t}$ & 1,894 & 1,806 & 1,732 & 1,612 \\
\hline Total carbon footprint, ${ }^{4,5} \times 10^{3} \mathrm{t}$ & 8,104 & 7,493 & 6,442 & 5,800 \\
\hline
\end{tabular}

${ }^{1}$ Yield response to rbST supplementation equaled $3.3 \mathrm{~kg} / \mathrm{d}$ (Holstein) and $3.4 \mathrm{~kg} / \mathrm{d}$ (Jersey) when corrected for calving interval and herd life.

${ }^{2}$ Refers to nutrients required for maintenance (all animals), pregnancy (dry cows), growth (heifers and adolescent bulls), and lactation (lactating cows).

${ }^{3}$ Based on rations formulated to meet nutrient requirements using alfalfa hay, corn silage, corn grain, and soybean meal as primary ingredients.

${ }^{4}$ Adjusted for the environmental impact of rbST manufacture.

${ }^{5}$ Total methane, nitrous oxide, and carbon dioxide emissions expressed as $\mathrm{CO}_{2}$-equivalents. 
factored into the analysis. In this context, maintenance is equivalent to the maintenance energy requirements of all animals within the population, plus energy required for pregnancy (dry cows) and growth (primiparous cows, replacement heifers and adolescent bulls). The reduction in individual Jersey animal BW resulted in a population body mass of $360.0 \times 10^{3} \mathrm{t}$ compared with $484.6 \times 10^{3} \mathrm{t}$ for the Holstein population. When the population maintenance requirement is taken into consideration, the total daily nutritional energy requirement of Cheddar cheese yielded by the Jersey population is $86 \mathrm{MJ} / \mathrm{kg}$ compared with $100 \mathrm{MJ} / \mathrm{kg}$ for the Holstein population. The mechanism by which the Jersey population reduces environmental impact per unit of Cheddar cheese yield is therefore based on both "reduction" and "dilution" of maintenance.

According to the first law of thermodynamics, energy cannot be created or destroyed, it can only change form. The daily energy requirement to feed the entire population can therefore be considered a proxy for resource use. This suggestion is borne out by the results in Table 3: because of the interplay between population BW and cheese yield, the Jersey population required $1,592 \times 10^{3} \mathrm{t}$ less feedstuffs, $98 \times 10^{3}$ fewer hectares of land, and $252 \times 10^{9}$ fewer liters of water to produce the same cheese yield as the Holstein population.

Extending system boundaries past the farm gate to the processing stage was beyond the scope of the current study. Setting the system boundaries at the manufacture of cropping inputs and ending at the farm gate provides for other LCA models for processing, retail, and consumption to build upon this work; such models should consider the effect of changes in whey production, excess cream, and so on. Nonetheless, we predict that the increase in nutrient density of milk produced by the Jersey population would result in less water being discarded during the cheese production process. Debate continues as to whether the earth can support the increase in population predicted to plateau in 2050, with land and water scarcity likely to lead to significant food shortages at the local level (Food and Agriculture Organization, 2008). Thus, management practices that allow the human population's demand for dairy products to be met while using less land and water per unit of food are a positive step toward maintaining future dairy industry sustainability.

Nutrient flows from animal production systems are of particular environmental concern because run-off into water systems increases the potential for eutrophication and consequent loss of water quality and biodiversity. The increased Cheddar cheese yield from Jersey milk reduced total $\mathrm{N}$ and $\mathrm{P}$ excretion by 17,234 $\mathrm{t}$ and 1,492 $\mathrm{t}$, respectively, and led to a $2,259 \times 10^{3} \mathrm{t}$ decrease in manure output compared with the Holstein population. Emissions from manure account for a significant proportion of total GHG attributed to dairy production (Food and Agriculture Organization, 2010); manure output therefore has a potentially adverse effect upon climate change. The total carbon footprint, expressed as the sum of $\mathrm{CO}_{2}$-equivalents $\left(\mathbf{C O}_{2}\right.$-eq $)$ carbon dioxide, methane, and nitrous oxide emissions was reduced by $20.5 \%$ by the use of Jersey milk, with carbon footprints of $6,442 \times 10^{3} \mathrm{t}$ of $\mathrm{CO}_{2}$-eq/500,000 t of cheese yield for the Jersey population compared with $8,104 \times 10^{3} \mathrm{t}$ of $\mathrm{CO}_{2}$-eq/500,000 $\mathrm{t}$ of cheese yield for the Holstein population. The scientific consensus is that GHG are forcing a change in climatic conditions that results in greater temperature variability for specific regions, although the immediate and future effects of this change upon human and animal populations have not been quantified with any degree of certainty (Moss et al., 2010). Nonetheless, reducing the carbon footprint per unit of cheese yielded is advantageous, both from a climate perspective and to ensure that the dairy industry continues to receive social license to function.

\section{The Effect of rbST Supplementation on Environmental Impact}

The use of rbST to improve productivity within the lactating cow herd allows for a reduction in resource use and environmental impact per unit of milk as detailed by Capper et al. (2008), Dunlap et al. (2000), and Johnson et al. (1992). The response to rbST supplementation is not proportional to milk yield - when animals are given the opportunity to increase DMI to account for greater milk production, milk yield shows a central tendency to increase by $4.5 \mathrm{~kg} / \mathrm{d}$. Given that the average Jersey cow within the current study produced $8.2 \mathrm{~kg}$ of milk/d less than the average Holstein cow, a yield increase of $4.5 \mathrm{~kg} / \mathrm{d}$ would be expected to have a greater effect upon resource use in the Jersey population than in the Holstein population.

The effect of rbST supplementation upon resource use and environmental impact in Jersey and Holstein populations is shown in Table 3. Milk nutrient density is unaffected by rbST supplementation (Barbano et al., 1988), thus the quantity of milk required to produce 500,000 t of Cheddar cheese was unchanged compared with that required from populations without rbST supplementation. As previously discussed, the environmental impact of rbST supplementation within a specific population is mediated through a change in population size, with fewer animals in both the Jersey and Holstein populations given rbST $\left(450 \times 10^{3}\right.$ and $417 \times 10^{3}$ animals, respectively) compared with their nonsupplemented counterparts $\left(524 \times 10^{3}\right.$ animals in the Jersey population and $465 \times 10^{3}$ animals in the Hol- 
stein population). The relative environmental impact of a $4.5-\mathrm{kg}$ increase in milk yield is revealed when changes in resource use and emissions are compared between supplemented and nonsupplemented Jersey and Holstein populations. Use of rbST in the Jersey population resulted in an $11.5 \%$ decrease in feed requirements per unit of cheese, a $12.0 \%$ decrease in water use, and an $8.4 \%$ decrease in land use compared with 7.4, 9.6, and $6.5 \%$ decreases in feed, water, and land requirements to produce 500,000 t of Cheddar cheese from the Holstein population. Manure production was reduced by $8.5 \%$ in the Jersey population given rbST supplementation compared with $7.3 \%$ in the Holstein population. As a consequence of the difference in baseline milk yield between the Jersey and Holstein populations, rbST supplementation had a greater effect upon the total GHG involved in producing Cheddar cheese from Jersey milk, with a $10.0 \%$ reduction in total carbon footprint compared with $7.5 \%$ in the Holstein population. The reduction in carbon footprint conferred by $\mathrm{rbST}$ supplementation of the Holstein population was similar to the results reported in a previous analysis from our group (Capper et al., 2008). The slight difference in the environmental impact of using rbST in the current study's Holstein population compared with that in the previous study can be attributed to the use of a model that has developed considerably in detail, complexity, and breadth since publication of the original paper.

\section{Evaluation of Performance Factor Effects Upon Environmental Impact}

The analysis was extended beyond the initial Jersey versus Holstein comparison to elucidate the extent to which specific performance characteristics are primarily responsible for the difference between these 2 breed populations. Figures 2 and 3 show the effect of switching a single characteristic between the Jersey and Holstein populations, independent of all other characteristics. Given the genetic and phenotypic correlations between performance characteristics, the results are not meant to reflect real-life situations, or to act as specific management recommendations; however, they demonstrate the magnitude of each characteristic's effect upon environmental impact within the current study. When characteristics were ranked according to their effect upon various resources used or environmental impacts, the rankings were similar, regardless of the resource or impact analyzed. In the interests of brevity, and in acknowledgment of their current status as environmental issues of concern, only carbon footprint and water use per unit of cheese yield are therefore provided.

The results indicated that BW, milk yield, and nutrient density differences between the 2 breeds had the greatest effect upon carbon footprint and water use per unit of cheese yield (Figures 2 and 3). As previously discussed, this underlines the importance of both

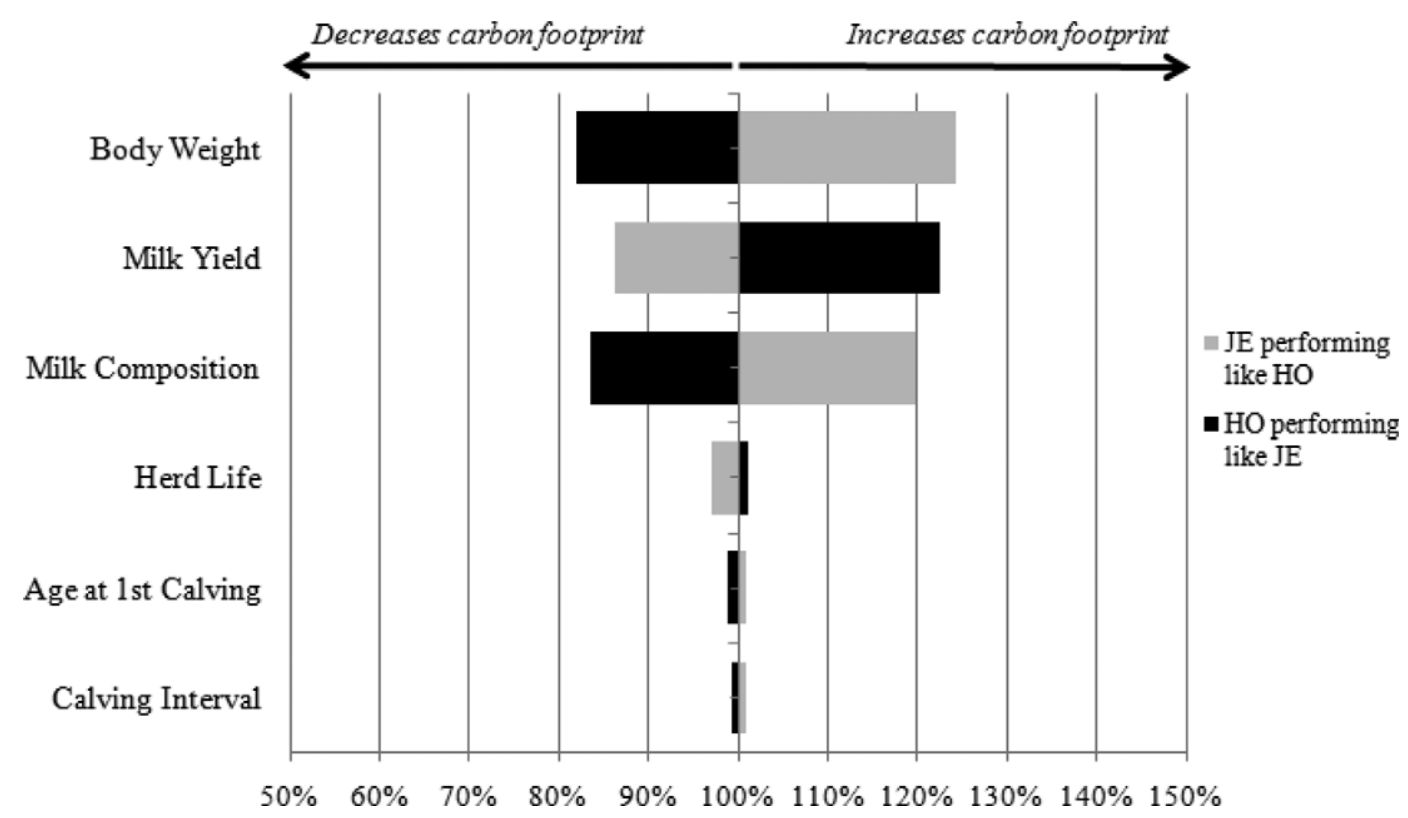

Figure 2. The effect of switching key breed-specific performance characteristics between Jersey and Holstein cattle on the carbon footprint of Cheddar cheese production. JE = Jersey cattle, $\mathrm{HO}=$ Holstein cattle; only one breed-specific performance trait was changed in each switch and all others remained constant; the carbon footprint is confined to greenhouse gas emissions produced within system boundaries extending from crop inputs to milk harvest and expressed as $\mathrm{CO}_{2}$-equivalents. 


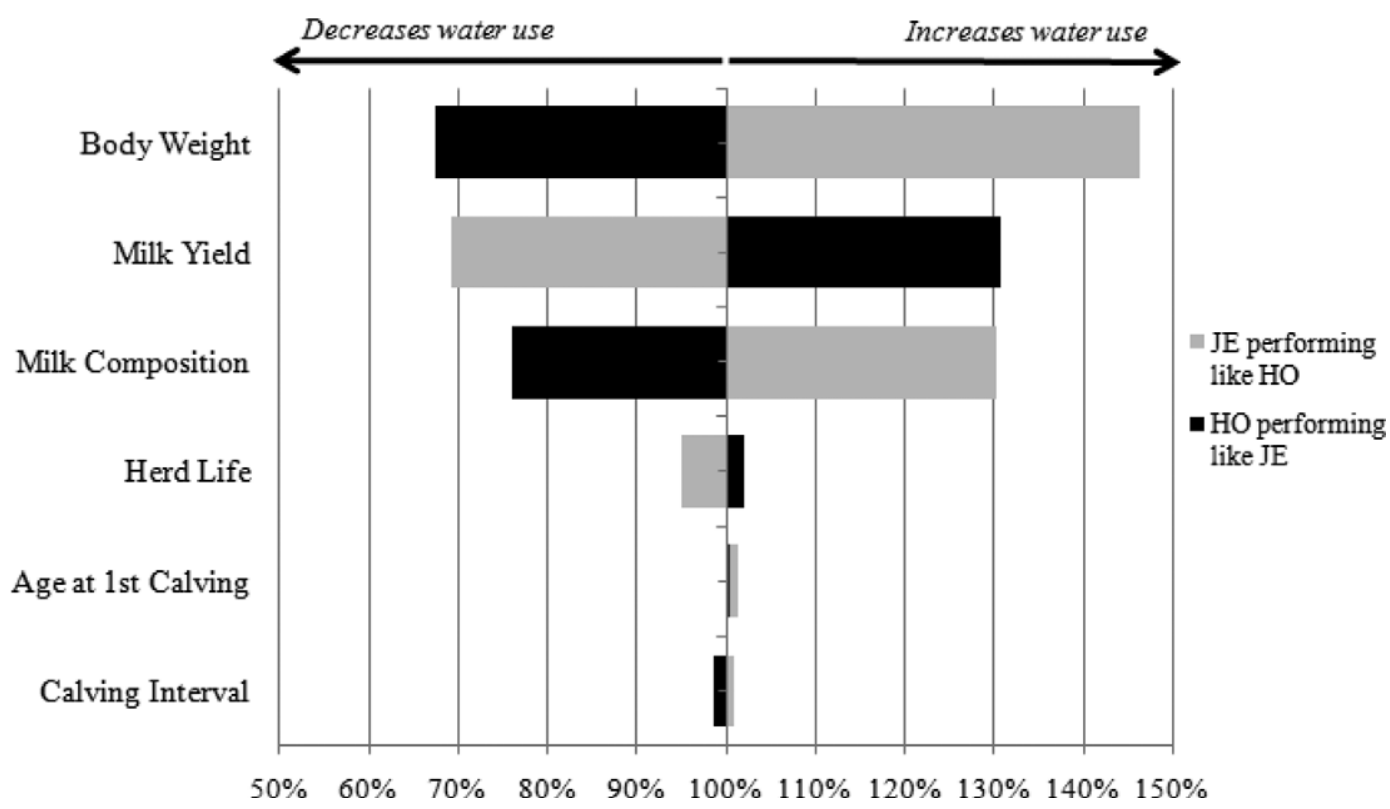

Figure 3. The effect of switching key breed-specific performance characteristics between Jersey and Holstein cattle on water use for Cheddar cheese production. $\mathrm{JE}=$ Jersey cattle $\mathrm{HO}=$ Holstein cattle; only one breed-specific performance trait was changed in each switch, and all others remained constant; water use refers to use within system boundaries extending from crop inputs to milk harvest.

reducing (BW) and diluting (milk yield and nutrient density) population maintenance as a means to reduce resource use and environmental impact. In contrast, variation in herd life, AFC, and CI had relatively small effects upon either water use or carbon footprint. The current study was based upon only 2 data points (average values for Jersey and Holstein populations) for the latter 3 performance characteristics, with relatively small differences between breeds. Further research into the effect of extending or reducing values for these performance traits to the range currently exhibited by the US dairy herd is therefore warranted to draw sound conclusions regarding their overall effect upon resource use and environmental impact as compared with BW, milk yield, and milk nutrient density.

Intuitively, it would seem that increasing herd life would reduce population maintenance costs because fewer replacement animals would be required within the supporting population. Given the current sensitivity regarding GHG emissions from dairy production, Garnsworthy (2004) suggested that reducing culling rate through improved cow fertility was a key factor in reducing methane emissions from the UK dairy herd. However, the current results suggest that an increase in herd life (Holstein animals performing like Jersey; Figures 2 and 3) would actually increase carbon footprint and water use per unit of milk. Jersey herd life is calculated as 3.00 lactations (Table 1) compared with 2.54 lactations for the Holstein population, which reduces the average milk yield per cow because the difference in time spent in the herd is during the lower-yielding portion of lactation. If the difference in herd life were such that the Jersey population extended their lifetime through the dry period and into the next lactation, a point would be reached at which average milk yield would be increased sufficiently to alter the results. The effect of herd life upon resource use and environmental impact warrants further investigation, as the response may not be linear but may vary according to the time spent in the various stages of lactation over the lifetime and the stage of lactation when an animal is culled.

Calving interval is closely associated with fertility (Garnsworthy, 2004) and an increase in average milk yield across the lactation (Oltenacu et al., 1981), with a greater proportion of time spent in early and mid lactation. The results in Figure 2 and 3 illustrate this association, with a decrease in carbon footprint and water use when CI is reduced from the Holstein baseline (14.1 mo) to that representative of the Jersey population (13.7 mo). Reducing AFC from 26.1 mo (Holstein population) to 25.3 mo (Jersey population) decreases the population maintenance requirement as heifers spend less time in the nonproductive period before entering the herd. This reduces the carbon footprint per unit of cheese yield (Figure 2), yet switching the AFC between either breed increases water use per unit of cheese (Figure 3). This seemingly anomalous result occurs through 2 mechanisms. First, increasing AFC (Jerseys performing like Holsteins) increases the population maintenance cost, thus increasing water requirements. Second, 
decreasing AFC (Holsteins performing like Jerseys) increases the growth rate required to reach adequate BW at calving $(544 \mathrm{~kg}$ ), thus increasing voluntary water intake and the use of irrigation-intensive feedstuffs (corn, soybean meal) within the ration. These results only hint at the complexity involved in determining the effect of reproductive efficiency and replacement program management on the environmental impact of dairy production and should serve as a warning against making intuitive and perhaps spurious claims without scientific support. These findings furthermore indicate the need for further research in this area.

Variation among studies in terms of methodology, inclusion of specific inputs and outputs, establishment of system boundaries, and differences in allocation strategies all lead to a great deal of difficulty in establishing a definitive carbon footprint or resource use value per $\mathrm{kg}$ of food produced. For example, recent LCA of US milk production have produced values ranging from 1.0 $\mathrm{kg}$ of $\mathrm{CO}_{2}-\mathrm{eq} / \mathrm{kg}$ of milk (Food and Agriculture Organization, 2010) to $1.35 \mathrm{~kg}$ of $\mathrm{CO}_{2}$-eq $/ \mathrm{kg}$ of milk (Capper et al., 2009). It should be noted that the principal objective of this study was to illustrate the potential for environmental impact reduction by changes in performance characteristics, rather than to provide a definitive value for the environmental impact of producing Cheddar cheese from either Jersey or Holstein milk. The current study is a point-in-time comparison based on data collected in November 2009 and thus the values for resource use or environmental impact cannot be assumed representative of all Jersey versus Holstein comparisons regardless of time point, population size, or geographical location. Indeed, the results would differ with any change in milk yield, milk nutrient density, or BW between the populations. Nonetheless, the delta and directional trends in resource use and environmental impact between populations may be referred to with confidence. Other dairy breeds that display performance characteristics intermediate between the 2 extremes used within the current study would be expected to have an environmental impact falling among the range displayed within this study.

\section{CONCLUSIONS}

Producing Cheddar cheese from Jersey milk consumes fewer natural resources and has a lower environmental impact compared with that using milk from Holstein cows. The interaction between improved milk nutrient density and reduced BW demonstrated by the Jersey population overcomes the reduced daily milk yield (compared with Holstein cows), thus reducing resource use and environmental impact per unit of cheese yield. Using rbST to improve productivity decreases consump- tion of natural resources and GHG emissions per unit of Cheddar cheese, with a greater effect in Jersey cows compared with Holstein cows because the incremental increase in milk yield due to rbST is equal across the 2 breeds but the proportional increase is greater in Jersey due to their lower baseline production. As concerns over the environmental impact of livestock production continue to grow, it is crucial to focus on both diluting (milk component yield) and reducing (BW) population maintenance requirements to further reduce natural resource use and the environmental impact of dairy production.

\section{REFERENCES}

AMTS. 2010. Dairy Pro. Agricultural Modeling and Training Systems, Cornell Research Foundation, Ithaca, NY.

Barbano, D. M., J. M. Lunch, D. E. Bauman, and G. F. Hartnell. 1988. Influence of sometribove (recombinant methionyl bovine somatotropin) on general milk composition. J. Dairy Sci. 71(Suppl. 1):101. (Abstr.)

Barnhart, S., M. Duffy, and D. Smith. 2008. Estimated Costs of Pasture and Hay Production. Iowa State University, Ames.

Bauman, D. E., R. W. Everett, W. H. Weiland, and R. J. Collier. 1999. Production responses to bovine somatotropin in northeast dairy herds. J. Dairy Sci. 82:2564-2573.

Capper, J. L., R. A. Cady, and D. E. Bauman. 2009. The environmental impact of dairy production: 1944 compared with 2007. J Anim. Sci. 87:2160-2167.

Capper, J. L., E. Castañeda-Gutiérrez, R. A. Cady, and D. E. Bauman. 2008. The environmental impact of recombinant bovine somatotropin (rbST) use in dairy production. Proc. Natl. Acad. Sci. USA 105:9668-9673.

Coggins, J. S. 1991. Predicting Cheddar cheese yield in an individual plant: Van Slyke revisited. J. Dairy Sci. 74:359-368.

Collier, R. J., J. C. Byatt, S. C. Denham, P. J. Eppard, A. C. Fabellar, R. L. Hintz, M. F. McGrath, C. L. McLaughlin, J. K. Shearer, J. J. Veenhuizen, and J. L. Vicini. 2001. Effects of sustained release bovine somatotropin (Sometribove) on animal health in commercial dairy herds. J. Dairy Sci. 84:1098-1108.

de Vries, A., and I. J. M. de Boer. 2010. Comparing environmental impacts for livestock products: A review of life cycle assessments. Livest. Sci. 128:1-11.

de Vries, A., M. Overton, J. Fetrow, K. Leslie, S. Eicker, and G. Rogers. 2008. Exploring the impact of sexed semen on the structure of the dairy industry. J. Dairy Sci. 91:847-856.

Dunlap, T. F., R. A. Kohn, G. E. Dahl, M. Varner, and R. A. Erdman. 2000. The impact of somatotropin, milking frequency, and photoperiod on dairy farm nutrient flows. J. Dairy Sci. 83:968-976.

Energy Information Administration. 2001. Updated State-Level Greenhouse Gas Emission Factors for Electricity Generation. US Department of Energy, Washington, DC.

Food and Agriculture Organization. 2006. Livestock's Long ShadowEnvironmental Issues and Options. Food and Agriculture Organization of the United Nations, Rome, Italy.

Food and Agriculture Organization. 2008. Coping with Water Scarcity: What Role for Biotechnologies? Food and Agriculture Organization of the United Nations, Rome, Italy.

Food and Agriculture Organization. 2010. Greenhouse Gas Emissions from the Dairy Sector: A Life Cycle Assessment. Food and Agriculture Organization of the United Nations, Rome, Italy.

Garnsworthy, P. C. 2004. The environmental impact of fertility in dairy cows: A modelling approach to predict methane and ammonia emissions. Anim. Feed Sci. Technol. 112:211-223.

Hartnell, G. F., S. E. Franson, D. E. Bauman, H. H. Head, J. T. Huber, R. C. Lamb, K. S. Madsen, W. J. Cole, and R. L. Hintz. 1991. Evaluation of sometribove in a prolonged-release system in lactat- 
ing dairy cows-Production responses. J. Dairy Sci. 74:26452663.

Hogan, C. 2009. Life Cycle Assessment of the Greenhouse Gas Emissions Embodied in Posilac ${ }^{\circledR}$. CAMCO, Broomfield, CO.

Holter, J. B. 1992. Water partitioning and intake prediction in dry and lactating Holstein cows. J. Dairy Sci. 75:1472-1479.

IPCC. 2006. IPCC Guidelines for National Greenhouse Gas Inventories. Institute for Global Environmental Strategies (IGES) for the IPCC, Kanagawa, Japan.

Johnson, D. E., G. M. Ward, and J. Torrent. 1992. The environmental impact of bovine somatotropin use in dairy cattle. J. Environ. Qual. 21:157-162.

Judge, L. J., R. J. Erskine, and P. C. Bartlett. 1997. Recombinant bovine somatotropin and clinical mastitis: Incidence, discarded milk following therapy, and culling. J. Dairy Sci. 80:3212-3218.

Kaspar, H. F., and J. M. Tiedje. 1981. Dissimilatory reduction of nitrate and nitrite in the bovine rumen: Nitrous oxide production and effect of acetylene. Appl. Environ. Microbiol. 41:705-709.

Keown, J. F., R. W. Everett, N. B. Empet, and N. H. Waddell. 1984. Lactation curves. J. Dairy Sci. 69:769-781.

Kirchgessner, M., W. Windisch, H. L. Muller, and M. Kreuzer. 1991. Release of methane and of carbon dioxide by dairy cattle. Agribiol. Res. 44:2-9.

Knight, C. H., M. Peaker, and C. J. Wilde. 1998. Local control of mammary development and function. Rev. Reprod. 3:104-112.

LudingtonD.PetersonR. C. 2005. How much energy does your dairy use? Northeast Dairy Business September:20-21.

McClary, D. G., H. B. Green, R. P. Basson, and S. C. Nickerson. 1994. The effects of a sustained-release recombinant bovine somatotropin (somidobove) on udder health for a full lactation. J. Dairy Sci. $77: 2261-2271$.

Moe, P. W., and H. F. Tyrrell. 1979. Methane production in dairy cows. J. Dairy Sci. 62:1583-1586.

Moss, R. H., J. A. Edmonds, K. A. Hibbard, M. R. Manning, S. K. Rose, D. P. van Vuuren, T. R. Carter, S. Emori, M. Kainuma, T. Kram, G. A. Meehl, J. Mitchell, N. Nakicenovic, K. Riahi, S. J. Smith, R. J. Stouffer, A. M. Thomson, J. P. Weyant, and T. J. Wilbanks. 2010. The next generation of scenarios for climate change research and assessment. Nature 463:747-756.

Mowrey, A., and J. N. Spain. 1999. Results of a nationwide survey to determine feedstuffs fed to lactating dairy cows. J. Dairy Sci. 82:445-451.

National Geographic. 2010. The Hidden Water We Use. Accessed July 25, 2010. http://environment.nationalgeographic.com/environment/freshwater/embedded-water.

National Milk Producers Federation. 2009. Dairy Producer Highlights. National Milk Producers Federation, Arlington, VA.

Oltenacu, P. A., T. R. Rounsaville, R. A. Milligan, and R. H. Foote. 1981. Systems analysis for designing reproductive management programs to increase production and profit in dairy herds. J. Dairy Sci. 64:2096-2104
Overton, M. W. 2005. Cost comparison of natural service sires and artificial insemination for dairy cattle reproductive management. Theriogenology 64:589-602.

Payne, J., and B. Pugh. 2011. On-Farm Mortality Composting of Livestock Carcasses. BAE-1749-3. Oklahoma State University, Stillwater.

Pell, A. N., D. S. Tsang, B. A. Howlett, M. T. Huyler, V. K. Meserole, W. A. Samuels, G. F. Hartnell, and R. L. Hintz. 1992. Effects of a prolonged-release formulation of Sometribove (n-methionyl bovine somatotropin) on Jersey cows. J. Dairy Sci. 75:3416-3431.

Peters, G. M., H. V. Rowley, S. Wiedemann, R. Tucker, M. D. Short, and M. S. Schultz. 2010. Red meat production in Australia: Life cycle assessment and comparison with overseas studies. Environ. Sci. Technol. 44:1327-1332.

Pimentel, D., and M. H. Pimentel. 2007. Food Energy and Society. 3rd ed. CRC Press, Boca Raton, FL.

Raubertas, R. F., and G. E. Shook. 1982. Relationship between lactation measures of somatic cell concentration and milk yield. J Dairy Sci. 65:419-425.

Ruegg, P. L., A. C. Fabellar, and R. L. Hintz. 1998. Effect of the use of bovine somatotropin on culling practices in thirty-two dairy herds in Indiana, Michigan and Ohio. J. Dairy Sci. 81:1262-1266.

Tauer, L. W., and W. A. Knoblauch. 1997. The empirical impact of bovine somatotropin on New York dairy farms. J. Dairy Sci. 80:1092-1097.

US EPA. 2010. Inventory of U.S. Greenhouse Gas Emissions and Sinks: 1990-2008. US EPA, Washington, DC.

USDA. 2007a. Dairy 2007, Part I: Reference of Dairy Cattle Health and Management Practices in the United States, 2007. USDAAPHIS-VS, Fort Collins, CO.

USDA. 2007b. Dairy 2007: Heifer Calf Health and Management Practices on U.S. Dairy Operations, 2007. USDA:APHIS;VS, Fort Collins, CO.

USDA-NASS. 2006. Agricultural Chemical Usage 2005 Field Crops Summary. USDA-NASS, Washington, DC.

USDA-NASS. 2007. Agricultural Chemical Usage 2006 Field Crops Summary. USDA-NASS, Washington, DC.

USDA-NASS. 2010. Accessed Nov 9, 2011. http://www.nass.usda.gov/ Data_and_Statistics/Quick_Stats/\#top.

West, T. O., and G. Marland. 2002. A synthesis of carbon sequestration, carbon emissions, and net carbon flux in agriculture: Comparing tillage practices in the United States. Agric. Ecosyst. Environ. 91:217-232.

White, T. C., K. S. Madsen, R. H. Sorbet, R. J. Collier, D. L. Hard, G. F. Hartnell, W. A. Samuels, G. de Kercove, F. Adriaens, N. Craven, D. E. Bauman, G. Bertrand, P. Bruneau, G. O. Gravert, H. H. Head, J. T. Huber, R. C. Lamb, C. Palmer, A. N. Pell, R. Phipps, R. Weller, G. Piva, Y. Rijpkema, J. Skarda, F. Vedeau, and C. Wollny. 1994. Clinical mastitis in cows treated with sometribove (recombinant bovine somatotropin) and its relationship to milk yield. J. Dairy Sci. 77:2249-2260. 